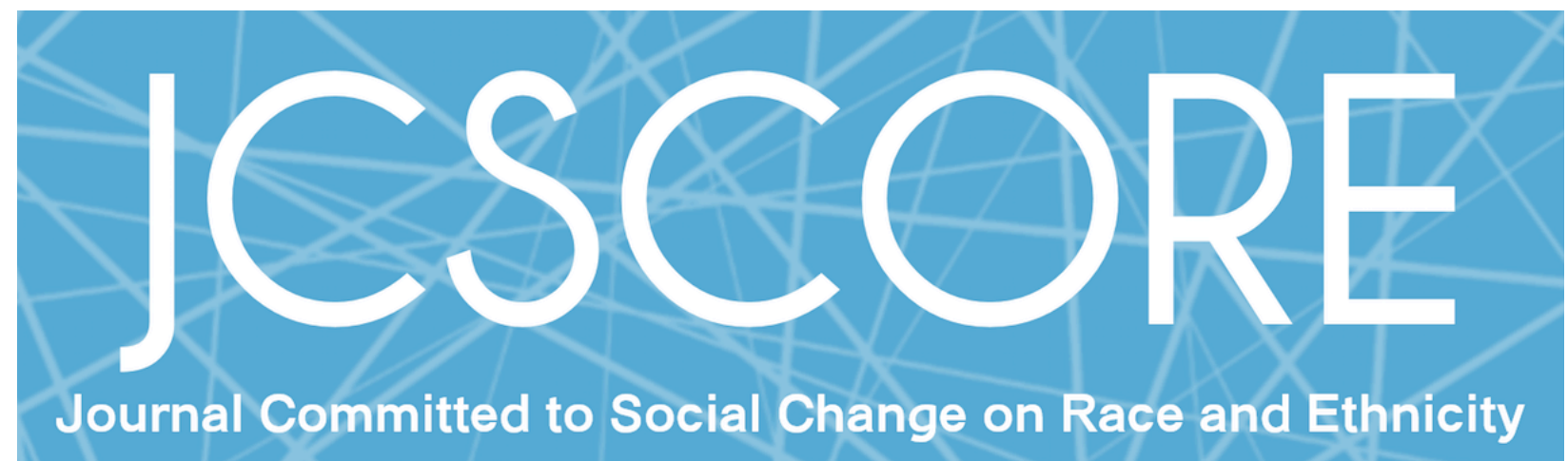

The Journal of the National Conference on Race and Ethnicity in American Higher Education

\title{
RACIAL COLOR-BLINDNESS AND PRIVILEGE AWARENESS IN RELATION TO INTEREST IN SOCIAL JUSTICE AMONG COLLEGE STUDENTS
}

Ja'Nina Garrett-Walker

University of San Francisco*

Sonja Martin Poole*

Sienna L. Williams*

Caleb J. Banks

Carnegie Mellon University

Justine A. Stallings*

Kristian R. Balgobin*

Dylan P. Moore*

Journal Committed to Social Change on Race and Ethnicity Volume 4, Issue 2 | 2018

Copyright $@ 2018$ Board of Regents of The University of Oklahoma on behalf of the Southwest Center for Human Relations Studies.

Permission of the Publisher is required for resale or distribution and for all derivative works, including compilations and translations. Quoting small sections of text is allowed as long as there is appropriate attribution. 


\title{
RACIAL COLOR-BLINDNESS AND PRIVILEGE AWARENESS IN RELATION TO INTEREST IN SOCIAL JUSTICE AMONG COLLEGE STUDENTS
}

\author{
Ja'Nina Garrett-Walker \\ University of San Francisco* \\ Sonja Martin Poole* \\ Sienna L. Williams* \\ Caleb J. Banks \\ Carnegie Mellon University \\ Justine A. Stallings* \\ Kristian R. Balgobin* \\ Dylan P. Moore*
}

\begin{abstract}
An online survey examining racial color-blindness, privilege awareness, and social justice was administered to a sample of 381 college students $\left(M_{\text {age }}=20.53, S D=\right.$ 4.35). Using multiple regression, increases in heterosexual and class privilege awareness predicted increases in student interest in social justice while increased levels of racial color-blindness predicted decreases in student interest in social justice. These findings suggest that racial color-blindness may serve as a barrier to engagement in social justice while heterosexual and class privilege awareness may buffer the aforementioned barrier. Professors and university administration should consider ways in which they infuse conversations around diversity, privilege, and racial color-blindness into their curriculum.
\end{abstract}

The notion that race does not matter - that the $21^{\text {st }}$ century is a post-racial era appears to be pervasive in the United States (Bonilla-Silva, 2014; Johnson, 2006).

Racial color-blindness contends that the best way to end discrimination is by treating individuals as equally as possible, without regard to race, culture or ethnicity (BonillaSilva, 2014; Neville, Awad, Brooks, Flores, \& Bluemel, 2013). However, research continues to illustrate the profound ways in which racial color-blindness negatively impacts race relations and an individual's ability to recognize racialized structures and 
practices (Apfelbaum, Sommers, \& Norton, 2008; Bonilla-Silva, 2014; Holoien \& Shelton, 2012; Richeson \& Nussbaum, 2004; Ryan, Hunt, Weible, Peterson, \& Casas, 2007). Acknowledgement of the existence of racialized, and other social privileges, appears to have the opposite effect (Case, 2007; Neville, Poteat, Lewis, \& Spanierman, 2014). People in dominant groups are frequently unaware, or deny, the existence of social privileges (Johnson, 2006; Mclntosh, 1988; Pratto \& Stewart, 2012). Being aware of social privileges and inequity, based on racial and other group identification differences (class, gender, sexual orientation, ability, religion), is squarely situated in social justice. Achieving social justice is predicated on collective awareness, understanding, and interest in issues related to dismantling systematic, structural, and institutional discriminatory practices and behaviors (Salinas \& Guerrero, 2018).

Intersectionality proposes that to reach liberation for all marginalized groups, a clear and conscious awareness of individual differences must be acknowledged and understood (Carastathis, 2016; Crenshaw, 1991; Ferber, 2012). Intersectionality scholars hold at the center of their articulations the need to dismantle racial colorblindness through the acknowledgment of racism, classism, sexism, ableism, and cissexism, in an effort to stay committed to social justice (Carastathis, 2016; Crenshaw, 1991; Ferber, 2012). Although research on racial color-blindness has predominantly examined interracial interactions, using intersectionality as a framework, the theoretical implications of racial color-blindness can, and should, be expanded to other social identities such as gender, sexual orientation, ability, religion, and social class (Collins, 2013; Crenshaw, 1991; Delgado \& Stefancic, 2012; Ferber, 2012; Johnson, 2006; Smith \& Shin, 2014). It is plausible that individuals who perpetuate racial color-blindness may 
also avoid conversations around other social privileges as well (Ferber, 2012). This study seeks to examine the relationship between racial color-blindness, privilege awareness (i.e., Christian privilege, class privilege, heterosexual privilege, male privilege, White privilege), and interest in social justice among college students.

\section{Social Justice and Interest in Social Issues}

Social justice is the equitable access to resources, the promotion of human rights, and the desire to transform a society's social and political climate to reflect the needs of marginalized groups (National Association of Social Works, 2015). Research has recently articulated the relationship between student interest in social issues and their future participation in the dismantling of social inequalities through social justice activities (Hurtado, 2003; Lewis, Neville, \& Spanierman, 2012; Todd, McConnel, \& Suffrin, 2014). In order to develop an interest in social justice, and be effective in social justice activities, it is necessary to be aware of structural inequalities. Todd et al. (2014) examined the relations between Christian conservatism, White privilege awareness, and interest in social justice among college students. They found that increased privilege awareness levels predicted interest in social justice action among participants (Todd et al., 2014). In regard to racial color-blindness and social justice attitudes, Lewis et al. (2012) found that students reporting higher levels of racial color-blindness were less likely to report interest in issues of social inequality. Higher education serves as a structure to instill equity-focused rhetoric and behavior into future generations. Within classrooms and campus events, students can be, and should be, challenged to dismantle power and privilege and dismantle the fallacy of racial color-blindness. Given that students within higher education go on to impact many sectors of society, it is 
Journal Committed to Social Change on Race and Ethnicity | 2018

imperative that they leave college with a lens that is focused on justice and social issues (Brennan, 2008; Brennan \& Naidoo, 2008). Past research seems to suggest the importance of examining racial color-blindness, privilege awareness, and interest in social justice simultaneously, although, to the authors knowledge, there have been no publications to date that examine all three constructs simultaneously.

\section{Racial Color-blindness}

Racial color-blindness is an ideology which posits that the most effective means of ending discrimination is through egalitarianism, without regard to race, culture, or ethnicity. This ideology is often promoted as a solution to race-related problems and is coupled with an avoidance of conversations about, or acknowledgement of, race (Apfelbaum et al., 2008; Bonilla-Silva, 2014; Neville et al., 2014; Tarca, 2005). Scholars have detailed the cognitive processes that individuals go through when prescribing to racial color-blindness. The denial of the permanence of racism (Bell, 1993; Sue, 2015), the emotional responses related to discussing race and racism (i.e., anxiety, fear, guilt) (Johnson, 2006; Sue, 2015), and the use of rhetorical tools such as projection and minimization (Bonilla-Silva, 2014) have maintained this modern form of racism. Racial color-blindness is often utilized by individuals within dominant groups to not be perceived as racist. However, such ideologies have been associated with increased bias toward marginalized groups and have been shown to have a negative effect on the experiences of people of color (Apfelbaum et al. 2008; Holoien \& Shelton, 2012; Richeson \& Nussbaum, 2004).

Apfelbaum et al. (2008) found that when White Americans were primed with racial color-blindness (especially with a Black confederate), they were substantially less 
likely to discuss race than participants primed to a race-acknowledged condition. When assessing implicit bias among White college students, participants primed with a racial color-blindness prompt reported significantly more racial bias than those primed with a multicultural prompt (Richeson \& Nussbaum, 2004). Holoien and Shelton (2012) found that when Asian American and Black American participants were paired with a White partner primed for a racial color-blindness, they performed poorly on a cognitive performance test when compared to their counterparts who were matched with a White partner primed for multiculturalism. Similarly, within the workforce, racial color-blindness of White employees was a significant predictor of their co-workers' (people of color) psychological engagement on the job (Plaut, Thomas, \& Goren, 2008). Individuals that adhere to racial color-blindness do not discuss or acknowledge systems that perpetuate social inequality. This line of thinking works in antithesis to the development of individuals who are dedicated to social issues and social justice (Apfelbaum et al., 2008; Ferber, 2012; Holoien \& Shelton, 2012; Hurtado, 2003; Lewis et al., 2012; Plaut et al., 2008; Richeson \& Nussbaum, 2004). Based on these previous findings, we hypothesize that:

Hypothesis 1: Increases in racial color-blindness will predict decreases in interest in social justice.

\section{Privilege Awareness}

Although researchers have argued that racial color-blindness is primarily a function of White privilege (Bonilla-Silva, 2014; Tarca, 2005), privilege is also imbedded in other social classifications. Privilege has been defined as access to unearned rights and advantages that are only provided to people within dominant social groups 
(Johnson, 2006; Mclntosh, 1988; McIntosh, 1989). In the United States, being born heterosexual, able-bodied, male, cisgender, Christian, or into a financially stable family often comes with various forms of material and symbolic privilege (Alexander, 2012; Bonilla-Silva, 2014; McIntosh, 1988; National Equal Pay Task Force, 2013). These resources, that are associated with social privilege, may positively influence an individual's health, happiness, safety, education, intelligence, and future opportunities (Crosley-Corcoran, 2014; Mclntosh, 1988). While access to privilege does not guarantee individual positive outcomes, it is considered an asset that is often denied to others based solely on group membership rather than talent, ability, or aspiration (Mclntosh, 1988).

Research investigating privilege and oppression has indicated that acknowledgement and discussion of privilege may lead to increased awareness of inequality and improves dominant attitudes toward oppressed groups (Becker, Zawadzki, \& Shields, 2014; Blumenfeld \& Jaekel, 2012; Case, 2007; Stewart, Latu, Branscombe, Phillips, \& Denney, 2012). Case (2007) found that students, who engaged in a course that explicitly addressed privilege and social oppression, were more aware of White privilege and racism at the end of the course. Similarly, Neville et al. (2014) found that students who took diversity related courses, and attended diversity activities on campus, reported decreases in racial color-blindness over their four-year college career. Stewart et al. (2012) found that when White participants, with high efficacy to reduce racial bias, were placed in a White privilege awareness group, they reported more positive views toward Black Americans. While most work on privilege awareness has historically focused on race, there has been some research that has explored 
privilege across other social categories and social settings. Case et al. (2012) engaged students and faculty in a series of participatory action research around the inclusion of transgender students. Although structural barriers prevented transgender inclusion policies at the university level, participants reported increased knowledge and awareness of cisgender privilege on an individual level (Case et al., 2012). Zawadzki, Shields, Danube, and Swim (2014) developed an experiential learning experience that increased participant awareness of male privilege and gender equity, in addition to decreasing participant sexist attitudes. Combined, these studies highlight the positive impact of having conversations about social group differences.

An inability, or unwillingness, to recognize differences in others makes it increasingly difficult to become aware of the ways in which privilege is ever present in society. The luxury of not acknowledging privilege is similar to the tenets of racial colorblindness where one is unwilling to see race by engaging in power and color evasion (Ferber, 2012; Neville et al, 2014; Johnson, 2006). Research has proposed that adoption of racial color-blindness may evolve from a lack of privilege awareness (Kleinman, Spanierman, \& Smith, 2015; Tarca, 2005). While racial color-blindness seems to be perpetuated by an inability to acknowledge the ways in which privileges permeate society, the acknowledgement of privilege may allow individuals to increase advocacy for disenfranchised groups. Based on these findings, we also hypothesize that:

Hypothesis 2: Increases in social privilege awareness will predict increases in interest in social justice. 
Journal Committed to Social Change on Race and Ethnicity | 2018

\section{Methods}

This research study investigated racial color-blindness and various social privileges as they relate to interest in social justice within a higher education setting utilizing online quantitative research methods.

\section{Participants and Procedures}

College students (296 women, 85 men, $M_{\text {age }}=20.53, S D=4.35$. range [17-57]) from a Jesuit University, with a focus on social justice in California, were recruited to participate in a 15-minute online survey, in fall 2014 , assessing their knowledge of social inequalities and engagement in social justice activities (See Table 1 for demographics). A stratified random sample of college students was provided by the University across major and academic standing. However due to a low response rate (10\%) additional participants were recruited through faculty emails to students. All faculty were provided with the same email script (that was sent to the stratified random sample) to send to their roster of students through CANVAS (a platform similar to Blackboard). The study protocol was approved by the University Institutional Review Board and participants indicated their consent through an online consent form.

\section{Measures}

Several measures were used to assess knowledge of various privileges (i.e., Christian privilege, class privilege, heterosexual privilege, male privilege), racial colorblindness, interest in social justice, and demographic characteristics (age, gender, ethnoracial identity, family income, year in college).

Class privilege awareness scale (CPAS). The CPAS, an adaptation of the White Privilege Attitudes Scale (Pinterits, Poteat, \& Spanierman, 2009) assessed 
Table 1. Demographic Characteristics of Participants

Demographic Characteristics as a Percentage of the Sample $(N=381)$

Ethnoracial Background

African Descent

$\mathrm{n}(\%)$

Asian Descent

$19(5.00)$

European Descent

$95(24.93)$

Latin Descent

$174(45.93)$

Multiracial

33 (8.66)

Other

$47(12.34)$

$12(3.14)$

Family Income

$<\$ 20,000$

$29(7.60)$

$\$ 21,000-40,000$

$59(15.50)$

$\$ 41,000-60,000$

85 (22.30)

$\$ 61,000-80,000$

$72(18.90)$

$>\$ 81,000$

136 (35.70)

Year in College

Freshmen

$118(31.00)$

Sophomore

84 (22.00)

Junior

88 (23.10)

Senior

Academic Discipline*

Liberal Arts

199 (65.70)

Professional

104 (34.30)

\section{Sexual Orientation}

Heterosexual

Queer

Note: Queer = any sexual orientation that is not heterosexual.

${ }^{*}$ missing data due to technical problem at the beginning of the data collection period

participant's attitudes toward class privilege. Twenty-eight questions examined awareness of class privilege through four subscales: willingness to confront class privilege, anticipated costs of addressing class privilege, awareness of class privilege, and remorse of class privilege. Each item was assessed on a 6-point Likert scale (1= strongly disagree to 6 = strongly agree) and subscales were summed for analysis. Only 
the awareness of class privilege subscale (four items) was utilized (e.g., Our social structure system promotes class privilege) (See Appendix A). Higher scores represent more awareness of class privilege (Cronbach's $\alpha=.70$ ).

Color-blind racial attitudes scale (CoBRAS). The CoBRAS (Neville, Lilly, Duran, Lee, \& Browne, 2000) evaluated the degree to which participants reported racial color-blindness. Such ideologies were assessed through acknowledgment of racial privilege, institutional discrimination, and blatant racial issues. Twenty questions (e.g., Racism may have been a problem in the past, but it is not an important problem today) were presented on a 6 -point Likert scale ( $1=$ strongly disagree to $6=$ strongly agree $)$. Mean total scores for each participant were used. Higher scores indicated greater racial color-blindness and greater unawareness of racial discrimination (Cronbach's $\alpha=.889$ ).

Privilege and oppression inventory (POI). The POI (Hays, Chang, \& Decker, 2007), a thirty-nine item questionnaire, examined participant awareness of White privilege (Cronbach's $\alpha=.928$; e.g., Whites generally have more resources and opportunities), heterosexual privilege (Cronbach's $\alpha=.919$; e.g., Gay, lesbian, and bisexual individuals do not have the same advantages as heterosexuals), Christian privilege (Cronbach's $\alpha=.922$; e.g., Christian holidays are given more prominence in society than non-Christian holidays), and male privilege (Cronbach's $\alpha=.904$; e.g., Women are not recognized in their careers as often as men). Items were scaled on a 6point Likert scale $(1=$ strongly disagree to $6=$ strongly agree $)$ and were summed, then divided by the number of items in the subscale, for scoring. Higher scores on each subscale represented more awareness of each privilege.

Interest in social justice. To measure students' interest in social justice, 
students completed Part III of the Social Issues Questionnaire (SIQ; Miller et al., 2009).

Part III assessed student interest in social justice issues/activitites (Cronbach's $\alpha=.896$;

e.g., How much interest do you have in volunteering your time at a community agency; reading about social issues (e.g., racism, oppression, inequality)). Each question was measured on a 10-point Likert scale $(0=$ not at all likely to $9=$ extremely likely). Items on each subscale were summed and then divided by the number of items in the subscale, for scoring.

\section{Data Analysis}

A series of Pearson correlations were run to explore the relationships between privilege awareness, racial color-blindness, and interest in social justice. $T$-test and oneway ANOVA with post-hoc tests were performed to determine if participants differed on the outcome variable, interest in social justice, based on demographic variables.

Gender was dichotomized based on the distribution of the data. Transgender women

Table 2

Correlation of key variables

\begin{tabular}{|l|c|c|c|c|c|c|c|}
\hline Measure & 1 & 2 & 3 & 4 & 5 & 6 & 7 \\
\hline 1. Interest in Social Justice & -- & $-0.44^{* *}$ & $0.39^{* *}$ & $0.25^{* *}$ & $0.39^{* *}$ & $0.33^{* *}$ & $0.33^{* *}$ \\
\hline 2. Racial color-blindness & & -- & $-0.74^{* *}$ & $-0.49^{* *}$ & $-0.61^{* *}$ & $-0.54^{* *}$ & $-0.69^{* *}$ \\
\hline $\begin{array}{l}\text { 3. Class Privilege } \\
\text { Awareness }\end{array}$ & & & -- & $0.47^{* *}$ & $0.55^{\star *}$ & $0.53^{\star *}$ & $0.59^{* *}$ \\
\hline $\begin{array}{l}\text { 4. Christian Privilege } \\
\text { Awareness }\end{array}$ & & & & -- & $0.68^{* *}$ & $0.66^{* *}$ & $0.75^{* *}$ \\
\hline $\begin{array}{l}\text { 5. Heterosexual Privilege } \\
\text { Awareness }\end{array}$ & & & & & -- & $0.78^{\star *}$ & $0.71^{* *}$ \\
\hline $\begin{array}{l}\text { 6. Male Privilege Awareness } \\
\text { 7. White Privilege } \\
\text { Awareness }\end{array}$ & & & & & & -- & $0.71^{* *}$ \\
\hline Mean & 6.23 & 2.64 & 4.65 & 4.40 & 4.66 & 4.90 & 4.42 \\
\hline Standard Deviation & 1.79 & 0.76 & 0.92 & 1.03 & 0.93 & 0.88 & 0.96 \\
\hline
\end{tabular}


Journal Committed to Social Change on Race and Ethnicity | 2018

Table 3

Demographic Differences on Outcome Variable

\begin{tabular}{|c|c|c|c|c|}
\hline & \multicolumn{2}{|c|}{$\begin{array}{l}\text { Interest in } \\
\text { Social Justice }\end{array}$} & \multirow[t]{2}{*}{ t-value } & \multirow[t]{2}{*}{$p$-value } \\
\hline & $M$ & $S D$ & & \\
\hline Gender & & & -3.02 & $p<.01$ \\
\hline Women & 6.37 & 1.78 & & \\
\hline Men & 5.72 & 1.71 & & \\
\hline Academic Discipline & & & 3.16 & $p<.01$ \\
\hline Liberal Arts & 6.41 & 1.78 & & \\
\hline Professional & 5.72 & 1.81 & & \\
\hline Sexual Orientation & & & -1.60 & $n s$ \\
\hline Queer & 6.51 & 1.60 & & \\
\hline \multirow[t]{2}{*}{ Heterosexual } & 6.15 & 1.83 & & \\
\hline & & & $f$-value & \\
\hline Ethnoracial Background & & & 3.82 & $p<.01$ \\
\hline African Descent & $7.60^{\mathrm{a}}$ & 0.83 & & \\
\hline Asian Descent & $5.74^{b}$ & 1.82 & & \\
\hline European Descent & $6.28^{c}$ & 1.79 & & \\
\hline Latin Descent & $6.41^{\mathrm{bc}}$ & 1.86 & & \\
\hline Multiracial & $6.28^{b c}$ & 1.68 & & \\
\hline Other & $6.38^{\mathrm{abc}}$ & 1.74 & & \\
\hline Year in College & & & 1.94 & ns \\
\hline Freshmen & 5.91 & 1.89 & & \\
\hline Sophomore & 6.26 & 1.55 & & \\
\hline Junior & 6.41 & 1.74 & & \\
\hline Senior & 6.43 & 1.86 & & \\
\hline Income & & & 1.74 & $n s$ \\
\hline$<\$ 20,000$ & 5.82 & 2.44 & & \\
\hline$\$ 21,000-\$ 40,000$ & 5.79 & 1.72 & & \\
\hline$\$ 41,000-\$ 60,000$ & 6.25 & 1.54 & & \\
\hline$\$ 61,000-\$ 80,000$ & 6.41 & 1.68 & & \\
\hline$>\$ 81,000$ & 6.39 & 1.84 & & \\
\hline
\end{tabular}

Note. Queer = any sexual orientation that is not heterosexual.

For post hoc comparisons, means that do not share a superscript letter are significantly different from one another at $p<.01$ using LSD comparison 
Journal Committed to Social Change on Race and Ethnicity | 2018

$(n=2)$ were collapsed with cisgender women, and transgender men $(n=2)$ were collapsed with cisgender men. Given the exploratory nature of this study a multiple regression was run, to determine which construct(s) (privilege awareness, racial colorblindness) most strongly predicted interest in social justice, over and beyond covariates.

\section{Results}

Correlational analyses revealed significant relations among study variables (see Table 2). Participants differed by gender, academic discipline (Poole \& Garrett-Walker, 2016), and ethnoracial background with regard to the outcome variable. Participants did not significantly differ on the outcome variable for any other demographic characteristics or

by recruitment strategy (Table 3). Given these findings, only gender, academic discipline, and ethnoracial background were utilized as covariates in the analysis.

\section{Regression Analysis}

A multiple regression analysis was run in an effort to predict interest in social justice (Table 4). When predicting interest in social justice, covariates were placed in the $1^{\text {st }}$ block of the model using enter method. The various privilege awareness constructs were placed in the second block while racial color-blindness was placed in the third block utilizing enter method. After controlling for covariates, class privilege awareness $(\beta=0.21, p<.01)$ and heterosexual privilege awareness $(\beta=0.23, p<.05)$ accounted for approximately $14 \%$ of the variance $\left(R^{2}=0.24, R^{2}\right.$ change $\left.=0.14, p<.001\right)$ when predicting interest in social justice. Racial color-blindness $(\beta=-0.28, p<.01)$ accounted for an additional $2 \%$ of the variance when predicting interest in social justice $\left(R^{2}=0.26\right.$, $R^{2}$ change $\left.=0.02, p<.01\right)$ 
Table 4

Multiple Regression Analysis for Variables Predicting Interest in Social Justice $(N=381)$

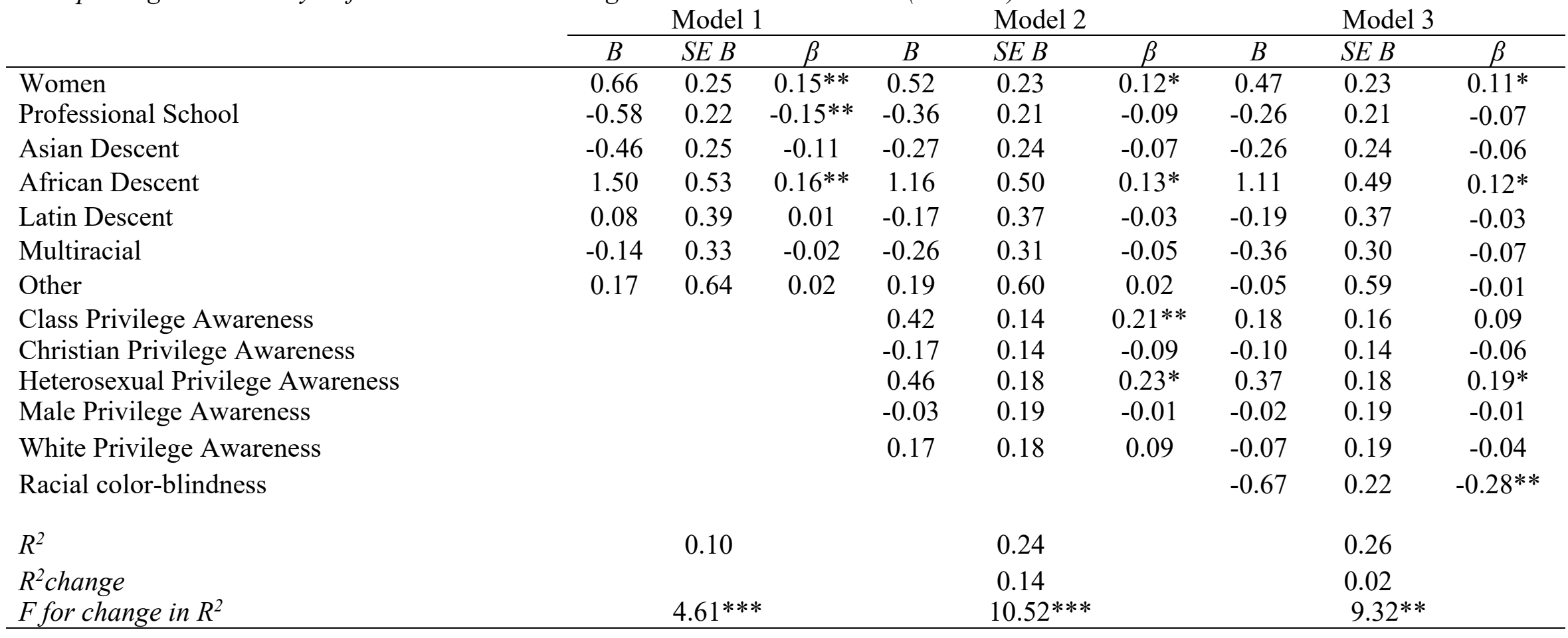

${ }^{*} p<.05 . * * p<.01 . * * * \mathrm{p}<.001$ 
Journal Committed to Social Change on Race and Ethnicity | 2018

\section{Discussion}

The current study sought to explore the predictive power of racial color-blindness and privilege awareness on interest in social justice. The findings from this study suggest that individuals who maintain racial color-blindness are less likely to show interest in social justice. However, individuals who are more aware of heterosexual and class privilege are more likely to report interest in social justice. Interestingly, heterosexual and class privilege were the only privilege awareness constructs that contributed to the model. The authors speculated that all forms of privilege awareness would predict interest in social justice. However, gender, religious, and racial privileges did not predict interest in social justice. This may be because conversations around gender, religion, and race are often silenced, making it difficult for individuals to become aware of such privilege (Ferber, 2012; Sue, 2015). For example, the existence of racial color-blindness and the post-feminism era have produced a cultural norm that racial and gender equality have already been achieved. If the current social conversation purports that privilege around gender, religion, and race do not exist (Ferber, 2012; Johnson, 2006; Sue, 2015) one can imagine that male privilege awareness, Christian privilege awareness, and White privilege awareness may not contribute to the development of interest in social justice.

Heterosexual privilege may have contributed to the model given the time in which the study was taken. Participants completed this survey roughly a year after the Defense Against Marriage Act was overturned. Given this historical governmental change, and increased LGBTQ+ representation in media and government, it is likely that participants awareness around LGBTQ+ issues were heightened. What is 
interesting is that class privilege, another silenced privilege (Sanders \& Mahalingam, 2012), also contributed to the model. Although conversations around class are difficult for individuals to engage in (Sanders \& Mahalingam, 2012), it may have contributed to the model given the class distribution of the University and the institutions focus on social justice. Given that a disproportionate number of participants came from upperclass families, yet attend a school focused on social justice, it is feasible that their awareness of their privilege is heightened. This awareness may fuel them to utilize the power and privilege that they do have, to advocate for others. As expected, over and above the privilege awareness constructs, racial color-blindness independently predicted interest in social justice. It is plausible that if individuals subvert racial colorblindness, they may be attuned to social inequity, and more interested in prosocial behavior (Freire, 1968; Bonilla-Silva, 2014).

In addition to these key findings, the demographic differences of participants also warrant attention. Participants who identified as men reported lower interest in social justice when compared to women. This may be because some men hold great privilege in various contexts. Being in such a position of power might make it difficult for some men to acknowledge the value in engaging to social justice activities because they may not directly benefit from such activities (Freire, 1968; Mclntosh, 1988). Participants also differed by academic discipline. Participants with a professional major (nursing, business) reported less interest in social justice when compared to liberal arts students (arts, humanities, social sciences, science). This finding suggests that faculty in schools of nursing and business should be diligent in their efforts to increase discussions around social justice (Poole \& Garrett-Walker, 2016). In regard to ethnoracial background, 
participants of Asian descent reported the lowest interest in social justice while participants of African descent reported the highest levels of interest. Students of Asian descent were disproportionately Business and Science majors. These majors tend to offer fewer courses and opportunities to discuss social inequity (when compared to social science majors) which may have impacted student interest and exposure to social justice (Poole \& Garrett-Walker, 2016). Regarding participants of African descent, this data was collected during the height of the protest in Ferguson, MI (Sanchez \& Lawler, 2015) following the police murder of Mike Brown. The momentum of those protests, and the Black Lives Matter movement, may have increased students of African descent interest in social justice.

\section{Implications for Higher Education}

Given that the participants of this study attend a university with social justice at the core of its identity, the findings of this study are particularly significant in our understanding of inequity. It is important to acknowledge that even in a setting where conversations around social justice are a common practice, community members may still perpetuate thought processes (i.e., racial color-blindness) that are in stark contrast to equity. Such ideologies may in turn impact social justice interest and involvement. These results support the need for a transformation in the ways in which individuals, and institutions, participate in the social milieu of racial color-blindness, privilege, and the associated structural inequalities. Examining these constructions, in addition to individual and collective commitment to equity and inclusion, supports the work of progressive colleges and universities. As such, this research offers several useful insights for thought leaders and higher education practitioners. First, the current findings 
indicate that college students in the United States would benefit from course content that includes real understanding of race and racism. Previous research has shown that learning about outgroups can increase awareness of privilege and discrimination, and in some cases, reduce bias and stereotypes (Blumenfeld \& Jaekel, 2012; Case, 2007; Kernahan, 2016; Muller \& Miles, 2017; Neville et al., 2014; Pettigrew, Tropp, Wagner, \& Christ, 2011; Sidanius, Levin, Van Laar, \& Sears, 2008). In particular, exposing students to courses and dialogues that connect them to the lived experiences of others supports them in their ability to think critically about social structures and inequity (Dessel, Rogge, \& Garlington, 2006; Lechuga, Clerc, \& Howell, 2009). However, this work should not be left to faculty of color, LGBTQ+ faculty, female identified faculty, or faculty with disabilities. This work needs to be embedded in all courses across all disciplines (not just social scientist).

While curricular experiences are important, work also needs to be done outside of the classroom (Kernahan, 2016; Lechuga et al., 2009). To promote understanding, empathy and trust among diverse groups, Universities should develop thoughtful events and initiatives that promote intergroup contact. Intergroup relations studies have found the more contact one has with an outgroup the less they report racial color-blindness and the more they report feelings of empathy toward their outgroup peers (Muller \& Miles, 2017; Pettigrew et al., 2011; Sidanius et al., 2008). Finally, a primary implication of this study lies in the area of professional development. Anti-bias training and education in the form of workshops, seminars, and ongoing programs have promise in this regard. Higher education professionals that engage in formal training will not only expand their understandings, but they may also be instrumental in weakening prevailing 
beliefs and ideologies that are deemed to harm marginalized people and discourage social justice action (Kernaha, 2016). Ideally, these trainings would be attended by all faculty and staff-- not just the faculty and staff who hold marginalized identities and do diversity work. To be truly effective, institutions need to hold all stakeholders responsible for helping students develop a social justice focused lens.

\section{Limitations and Future Research}

Although the findings of this study begin to shed light on the relationship between these constructs, there are a few limitations that must be acknowledged. It is important to note the disproportionate number of women participants compared to men participants $(22 \%$ of the sample identified as men compared to $37 \%$ of the student population). Similarly, the family income of the sample was disproportionately high with only $23.1 \%$ of participants reporting a family income below $\$ 41,000$ a year. Additionally, the sample for this study was drawn from one university that is particularly situated within a social justice paradigm. Researchers should continue this line of inquiry across different college campuses (i.e., Historically Black Colleges and Universities, public universities, college and universities without a social justice framework) and developmental stages (i.e., K-12 education). Another important limitation is the recruitment of participants. We are aware that there is a level of selection bias regarding 1) student interest to complete the survey and 2) faculty dissemination of the survey. Last, it is important to note that quantitative methods alone cannot fully grasp the complexities of racial color-blindness nor privilege awareness. Mixed method designs would better serve in untangling the intersections of these socially imbedded constructs. These limitations notwithstanding, this work is important in helping us conceptualize the 
intricacies of these constructs. The results also underline the need to explore the various ways in which privilege awareness may buffer the negative effects of racial color-blindness and how racial color-blindness may be inhibiting individuals from developing an interest in social justice to advocate for those who may be marginalized. This work challenges us to conceptualize ways in which we can help individuals translate ethical principles into purposeful societal practices to reach social justice (Jasso, 2015; Sabbagh \& Resh, 2016).

This conceptualization will require a deep and critical analysis given that what is regarded as societal progress (i.e., racial color-blindness) often masks more pernicious social perceptions (i.e., reduced interest in social justice). In order to unveil the problematic aspects of racial color-blindness, concrete situations should be examined for future research, wherein the mask of equality may hide the menace of social justice apathy (Ferber, 2012). In this way, the individual privileges of particular citizens, and their aspirations for a socially color-blind society, can be decoupled from the collective achievement of social justice as an ethical goal. The future directions for research should clarify and specify how and why racial color-blindness propagation causes harm to society (Bonilla-Silva, 2014; Ferber, 2012) by diminishing interest in social justice activism and policies. Initially, this move towards concrete situations will require a thoughtful consolidation of the extant theories and literature across many interrelated disciplines. This theoretical consolidation itself will be a meaningful contribution to the social justice literature, by framing racial color-blindness as one of many factors which may impede social justice - intentionally or unintentionally. 
Social justice literature suggests that educational environments are ideal settings to have these conversations (Bell, 2007; Case, 2007, 2012; Kernahan \& Davis, 2010; Sabbagh \& Resh, 2016; Salinas \& Guerrero, 2018; Simoni \& Walters, 2001; Spanierman, Neville, Liao, Hammer, \& Wang, 2008; Watt, 2007) and increase our understanding of how racial color-blindness and privilege awareness may be intertwined in our conceptualizations of social justice. It is thus the duty of educators everywhere, to think critically about the ways in which conversations around privilege, racial colorblindness, and social justice can be discussed in classrooms. School administrators must hold themselves, and their colleagues accountable, when unjust behaviors are exemplified in classrooms by faculty and students. It is the moral obligation of all educators, to ensure that they are working toward a true just and inclusive world, that does not allow for any citizen to be blinded by their own power and privilege (Freire, 1968; Johnson, 2006; Sue; 2015; Watt, 2007). 


\section{References}

Alexander, M. (2012). The New Jim Crow: Mass Incarceration in the Age of Colorblindness. New York: New Press.

Apfelbaum, E. P., Sommers, S. R., \& Norton, M. I. (2008). Seeing race and seeming racist? Evaluating strategic colorblindness in social interaction. Journal of Personality and Social Psychology, 95, 918-932.

Becker, J. C., Zawadzki, M. J., \& Shields, S. A. (2014). Confronting and reducing sexism: A call for research on intervention. Journal of Social Issues, 70, 603-614.

Bell, D. (1993). Faces at the bottom of the well. New York: Basic Books.

Bell, L. A. (2007). Theoretical foundations for social justice education. Teaching for Diversity and Social Justice, 2, 1-14.

Blumenfeld, W. J. \& Jaekel, K. (2012), Exploring Levels of Christian Privilege Awareness among Preservice Teachers. Journal of Social Issues, 68, 128-144.

Bonilla-Silva, E. (2014). Racism without Racists: Color-blind Racism and the Persistence of Racial Inequality in America. Lanham, MD: Rowman \& Littlefield.

Brennan, J. (2008). Higher education and social change. Higher Education, 56, 381393.

Brennan, J. \& Naidoo, R. (2008). Higher education and the achievement (And/or prevention) of equity and social justice. Higher Education, 56, 287-301.

Carastathis, A. (2016). Intersectionality: Origins, Contestations, Horizons. Lincoln, NE: University of Nebraska.

Case, K. A. (2007). Raising white privilege awareness and reducing racial prejudice: Assessing diversity course effectiveness. Teaching of Psychology, 34, 231-235.

Case, K. A., Kanenberg, H., Erich, S., \& Tittsowrth, J. (2012). Transgender inclusion in university nondiscrimination statements: Challenging gender-conforming privilege through student activism. Journal of Social Issues, 68, 145-161.

Collins, P. H. (2013). Toward a new vision: race, class, and gender. In M. Adams, W. Blumenfeld, C. Castañeda, H. Hackman, M. Peters, \& X. Zúñiga (Eds.), Readings for Diversity and Social Justice (pp. 606-611). New York: Routledge.

Crenshaw. K. (1991). Mapping the margins: Intersectionality, identity politics, and violence against Women of Color. Stanford Law Review, 43, 1241-1299.

Crosley-Corcoran, G. (2014, September 3). Explaining white privilege to a broke white person. Huffington Post. Retrieved from http://www.huffingtonpost.com/ginacrosleycorcoran/explaining-white-privilege-to-a-broke-whiteperson_b_5269255.html

Delgado, R. \& Stefancic, J. (2012). Critical Race Theory. New York: NYU Press.

Dessel, A., Rogge, M. E., \& Garlington, S. B. (2006). Using intergroup dialogue to promote social justice and change. Social Work, 51, 303-315.

Ferber, A. (2012). The culture of privilege: Color-blindness, postfeminism, and Christonormativity. Journal of Social Issues, 68, 63, 77.

Freire, P. (1968). Pedagogy of the oppressed. New York: Seabury.

Hays, D. G., Chang, C. Y., \& Decker, S. L. (2007). Initial development and psychometric data for the Privilege and Oppression Inventory. Measurement and Evaluation in Counseling and Development, 40, 66-79. 
Holoien, D. S. \& Shelton, J. N. (2012). You deplete men: The cognitive costs of colorblindness on ethnic minorities. Journal of Experimental Social Psychology, 48, 562-565.

Hurtado, S. (2003). Preparing college students for a diverse democracy (Final report to the U.S. Department of Education, Office of Educational Research and Improvement, Field Initiated Studies Program). Ann Arbor, MI: Center for the Study of Higher and Postsecondary Education.

Jasso, G. (2015). Thinking, saying, doing in the world of distributive justice. Social Justice Research, 28, 435-478.

Johnson, A. G. (2006). Privilege, Power, and Difference. Boston, MA: McGraw Hill.

Kernahan, C. (2016). Raising awareness and reducing color-blind racial ideology in higher education. In. H. A. Neville, M. E. Gallardo, \& D. W. E. Sue (Eds.), The Myth of Racial Color Blindness: Manifestations, Dynamics, and Impact (227-241). Washington, DC: American Psychological Association.

Kernahan, C. \& Davis, T. (2010). What are the long-term effects of learning about racism? Teaching of Psychology, 37, 41-45.

Kleinman, S., Spanierman, L. B., \& Smith, N. G. (2015). Translating oppression: Understanding how sexual minority status is associated with White men's racial attitudes. Psychology of Men \& Masculinity, 16, 404-415.

Lechuga, V. M., Clerc, L. N., \& Howell, A. K. (2009). Power, privilege, and learning: Facilitating encountered situations to promote social justice. Journal of College Student Development, 50, 229-244.

Lewis, J. A., Neville, H. A., \& Spanierman, L. B. (2012). Examining the influence of campus diversity experiences and color-blind racial ideology on students' social justice attitudes. Journal of Student Affairs Research and Practice, 49, 119-136.

Mclntosh, P. (1988). White privilege and male privilege: A personal account of coming to see correspondences through work in women's studies (Working Paper No. 189). Wellesley, MA: Wellesley Centers for Women.

Miller, M. J., Sendrowitz, K., Connacher, C., Blanco, S., Muñiz de la Peña, C., Bernardi, S., \& Morere, L. (2009). College students' social justice interest and commitment: A social-cognitive perspective. Journal of Counseling Psychology, 56, 495-507.

Muller, J. T. \& Miles, J. R. (2017). Intergroup dialogue in undergraduate multicultural psychology education: Group climate development and outcomes. Journal of Diversity in Higher Education, 10, 52-71.

National Association of Social Works. (2015). Social Justice. Retrieved from https://www.socialworkers.org/pressroom/features/issue/peace.asp

National Equal Pay Task Force. (2013). Fifty Years After the Equal Pay Act. Retrieved from https://www.whitehouse.gov/sites/default/files/equalpay/equal_pay_task_force_pr ogress_report_june_2013_new.pdf

Neville, H. A., Awad, G. H., Brooks, J. E., Flores, M. P., \& Bluemel, J. (2013). Colorblind racial ideology: Theory, training, and measurement implications in psychology. American Psychologist, 68, 455-466.

Neville, H. A., Lilly, R. L, Duran, G., Lee, R. M., Browne, L. (2000). Construction and Initial Validation of the Color-Blind Racial Attitudes Scale (CoBRAS). Journal of Counseling Psychology, 47, 59-70. 
Neville, H. A., Poteat, V. P., Lewis, J. A., \& Spanierman, L. B. (2014). Changes in White college students' color-blind racial ideology over 4 years: Do diversity experiences make a difference? Journal of Counseling Psychology, 61, 179-190.

Pettigrew, T. F., Tropp, L. R., Wagner, U., \& Christ, O. (2011). Recent advances in intergroup contact theory. International Journal of Intercultural Relations, 35(3), 271-280.

Pinterits, E. J., Poteat, V. P., \& Spanierman, L. B. (2009). The White Privilege Attitudes Scale: Development and Initial Validation. Journal of Counseling Psychology, 56, 417-429.

Plaut, V. C., Thomas, K. M., \& Goren, M. J. (2008). Is multiculturalism or colorblindness better for minorities? Psychological Science, 20, 444-446.

Poole, S. M. \& Garrett-Walker, J. J. (2016). Are future business professionals ready for multicultural marketing? An investigation of undergraduate students. Journal of Cultural Marketing Strategy, 2, 43-50.

Pratto, F. \& Stewart, A. L. (2012). Group dominance and the half-blindness of privilege. Journal of Social Issues, 68, 28-45.

Richeson, J. A., \& Nussbaum, R. J. (2004). The impact of multiculturalism versus colorblindness on racial bias. Journal of Experimental Social Psychology, 40, 417423.

Ryan, C. S., Hunt, J. S., Weible, J. A., Peterson, C. R., \& Casas, J. F. (2007). Multicultural and colorblind ideology, stereotypes, and ethnocentrism among Black and White Americans. Group Processes \& Intergroup Relations, 10, 617637.

Sabbagh, C., \& Resh, N. (2016). Unfolding justice research in the realm of education. Social Justice Research, 29, 1-13.

Sanchez, R. \& Lawler, D. (2015, Aug 10). Ferguson: timeline of events since Michael Brown's death. The Telegraph. Retrieved from https://www.telegraph.co.uk/news/worldnews/northamerica/usa/11242108/Fergu son-timeline-of-events-since-Michael-Browns-death.html

Sanders, M. R. \& Mahalingam, R. (2012). Under the radar: The role of invisible discourse in understanding class-based privilege. Journal of Social Issues, 68, 112-127.

Salinas, C., \& Guerrero, V. (2018). Tokenizing social justice. In P. Sasso \& J. DeVitis (Eds), Colleges at the crossroads: Taking sides on contested issues, (pp. 161179). New York; Peter Lang.

Sidanius, J., Levin, S., Van Laar, C., \& Sears, D. O. (2008). The diversity challenge: Social identity and intergroup relations on the college campus. Russell Sage Foundation.

Simoni, J. M. \& Walters, K. L. (2001). Heterosexual identity and heterosexism: Recognizing privilege to reduce prejudice. Journal of Homosexuality, 41, 157172.

Smith, L. C. \& Shin, R. Q. (2014). Queer blindfolding: A case study on difference "blindness" toward persons who identify as lesbian, gay, bisexual, and transgender. Journal of Homosexuality, 61, 940-961.

Spanierman, L. B., Neville, H. A., Liao, H. Y., Hammer, J. H., \& Wang, Y. F. (2008). Participation in formal and informal campus diversity experiences: Effects on 
students' racial democratic beliefs. Journal of Diversity in Higher Education, 1 , 108-125.

Stewart, T. L., Latu, I. M., Branscombe, N. R., Phillips, N. L., \& Denney, H. T. (2012). White privilege awareness and efficacy to reduce racial inequality improve White Americans' attitudes toward African Americans. Journal of Social Issues, 68, 1127.

Sue, D. W. (2015). Race Talk and the Conspiracy of Silence: Understanding and Facilitating Difficult Dialogues on Race. Hoboken, NJ: Wiley.

Tarca, K. (2005). Colorblind in control: The risks of resisting difference amid demographic change. Educational Studies, 38, 99-120.

Todd, N. R., McConnell, E. A., \& Suffrin, R. L. (2014). The role of attitudes toward White privilege and religious beliefs in predicting social justice interest and commitment. American Journal of Community Psychology, 53, 109-121.

Watt, S. K. (2007). Difficult dialogues, privilege, and social justice: Uses of the privileged identity exploration model in student affairs practice. The College Student Affairs Journal, 26, 114-126.

Zawadzki, M. J., Shields, S. A., Danube, C. L., \& Swim, J. K. (2014). Using WAGES to raise awareness of and reduce endorsement of sexism via experiential learning. Psychology of Women Quarterly, 38, 75-92. 


\section{Appendix A.}

Class Privilege Attitudes Scale

(Adapted from White Privilege Attitudes Scale)

Pinterits, E. J., Poteat, V. P., \& Spanierman, L. B. (2009). The White Privilege Attitudes Scale: Development and Initial Validation. Journal of Counseling Psychology, 56, 417-429.

Below is a set of descriptions of different attitudes about class (financial) privilege in the United States. Using the scale below, please rate the degree to which you personally agree or disagree with each statement. Please be as open and honest as you can; there are no right or wrong answers.

$\begin{array}{lllllcc}1 & 2 & 3 & 4 & 5 & 6 \\ \begin{array}{l}\text { Strongly } \\ \text { Disagree }\end{array} & & & & & & \text { Agree }\end{array}$

1. I plan to work to change our unfair social structure that promotes class privilege.

2. Our social structure system promotes class privilege.

3. I am angry that I keep benefiting from class privilege.

4. I am worried that taking action against class privilege will hurt my relationships with other wealthy people.

5. I take action against class privilege with people I know.

6. Everyone has equal opportunity, so this so-called class privilege is really wealthbashing.

7. I accept responsibility to change class privilege.

8. I feel awful about class privilege.

9. If I were to speak up against class privilege, I would fear losing my friends.

10. I have not done anything about class privilege.

11. I am ashamed of my class privilege.

12. I look forward to creating a more economically-equitable society.

13. I am anxious about the personal work I must do within myself to eliminate class privilege.

14. I intend to work towards dismantling class privilege.

15. I am ashamed that the system is stacked in my favor because I am wealthy.

16. I don't care to explore how I supposedly have unearned benefits from being wealthy.

17. If I address class privilege, I might alienate my family.

18. I am curious about how to communicate effectively to break down class privilege.

19. Wealthy people have it easier than poorer people.

20. I'm glad to explore my class privilege.

21. I am angry knowing I have class privilege.

22. I worry about what giving up some class privileges might mean for me.

23. I want to begin the process of eliminating class privilege.

24. Plenty of people of low socio-economic status are more privileged than wealthy people.

25 . Wealthy people should feel guilty about having class privilege.

26. I take action to dismantle class privilege.

27. I am anxious about stirring up bad feelings by exposing the advantages that wealthy people have.

28. I am eager to find out more about letting go of class privilege

Note: Bolded questions should be reverse coded 